\title{
Tolga Akalın
}

Gazi University, tolgaakalin@gazi.edu.tr, Ankara-Türkiye

\section{http://dx.doi.org/10.12739/NWSA.2013.8.4.D0139}

\section{DÜNYADA OLAN ÜÇ ÖNEMLI SAVAŞIN ETKİSIYYL OLUŞAN RESIMMLER}

\section{ÖZET}

Savaş döneminde yaşamış insanların o anki duygularını ve acılarını yine o dönemde yaşamış sanatçıların gözünden görmek daha kalıcı ve etkili olmaktadır. Yaşadıkları döneme tanıklık eden sanatçılarının beyinlerinden süzülerek meydana gelen eserlerin günümüz insanının önüne sanat eseri ve aynı zamanda da bir belge olarak konulması çalışmanın amacını oluşturmaktadır. Araştırmanın kapsamını Fransız Devrimi, Birinci Dünya Savaşı ve Vietnam Savaşı'nı konu edinen sanatçılar ve onların eserleri oluşturmaktadır. Yöntem olarak betimsel analiz, içerik analizi ve literatür tarama tekniği kullanılmıştır. Çalışmada; ele alınan eserler yoluyla farklı zamanlarda yaşanan acı, yokluk, ölüm ve sefalet gibi olumsuz durumları yaşamış toplumların sanatçılarının ortaya koydukları eserlerde teknik olarak farklılıklar olsa bile duygu yönünden benzerlik gösterdiği sonucuna ulaşılmıştır.

Anahtar Kelimeler: Fransız Devrimi, Birinci Dünya Savaşı, Vietnam Savaşı, Savaş Resimleri, Sanat ve Politika

\section{PAINTINGS CREATED BY THE EFFECT OF THREE WARS ON EARTH}

\section{ABSTRACT}

It is more consistent and efficient to see the feelings and the pain of the people of the war era, through the eyes of the artist who lived at the same years. The artworks, gliding from the brains of the artists who witness their era, are submitted to contemporary people both as artworks and documents. This forms the aim of the work. The content was built up by the artists and the works about French Revolution, I. World War and Vietnam War. Literature scanning technique was used as a method. It is concluded by the artworks in the study that; even if there are some technical differences in works of the artists who belonged to the societies which negative situations were widely experienced like death, misery, poverty and agony, there are some similarities about emotions, as well.

Keywords: French Revolution, I. World War, Vietnam War, War Pictures, Art and Policy 


\section{GÍRIŞ (INTRODUCTION)}

Bazı teorisyenler sanatı, bireyin herhangi bir malzeme kullanarak kendi içsel duygularını ve düşüncelerini görsel, işitsel veya bunlara benzer bir dille ifade etme eylemi olduğunu savunurlar. Bireyin duygularını ifade etme eylemini ilk insanın varlığına kadar götürmek mümkündür. İlk insanların korkularını, sevinçlerini, av törenlerini, ritüellerini kısacası yaşadıkları durumları ifade etmek için mağara duvarlarına resim yaptıkları bilinmektedir.

Bu düşünceye göre sanat sadece bireyin kendini ifade etme biçimi olarak algılanabilir. Sanat, bireyin kendisini ifade etme biçimlerinden birisi ise "Her ifade biçimi sanat mıdır?" sorusu akla gelebilir. Tabi ki her ifade biçimini sanat olarak nitelendiremeyiz. Bir ifade biçiminin sanat olarak nitelendirilebilmesi için gerekli olan bazı ölçütler vardır. Sanatın bireye özgü olması ve insanların iç dünyalarını yansıtması sanat ölçütleri arasında sayılabilir. Ancak bu ölçütlerin en başında dönemin olaylarına ve yaşam biçimlerine tanıkıık etmesinin de geldiği unutulmamalıdır.

Tabi ki dünyada yaşamış ilk insanlarla şu anda yaşamını sürdüren insanlar arasında duygu, düşünce ve ifade anlamında hesaplanamayacak kadar çok farklılık vardır. İlk insanların yaşam kaygılarını barınma, beslenme ve doğa olaylarından kendilerini koruma gibi basit durumlar oluştururken; günümüz insanının bu durumlar karşısında kaygılarının çoğunu ortadan kaldırdığı ve hatta bazı doğa olaylarına müdahale etmeye bile başladığı bilinmektedir. Bu yüzden insanlığın yaşam kaygıları ve beklentileri değişmiştir. Bu beklentilerin değişimi ile sanat anlayışının, sanatı ifade biçimlerinin ve aynı zamanda sanatı oluşturmak için kullanılan gereçlerin değişmesi de kaçınılmaz olmuştur. O halde sanatın ilk ortaya çıktığı zamanki algılanışı ile günümüzdeki algılanışının farklı olduğunu söylemek mümkündür.

Sanatın ortaya çıktığı zamandan günümüze kadarki süreç içinde bazı dönemler öne çıkmıştır. Bu dönemler insan hayatının değişimini etkilediği gibi sanatın gelişimini de etkilemiştir. En önemlilerinden biri de, Fransız Devrimídir. Aydınlanma çă̆ının başlangıç olaylarından biri olarak ele alınan Fransız Devrimi'nde yapılan mücadelenin insanların isteklerini, arzularını ve ütopyalarını çeşitlendirmesinin günümüz yaşam şekillerini ve sanat anlayışını da etkilediği yadsınamaz bir gerçek olarak karşımıza çıkmaktadır. Ayrıca, Birinci Dünya Savaşı ve Vietnam Savaşı'nın da dünyanın değişim sürecindeki önemli dönüm noktalarından olduğu bilinmektedir. Dünyanın değişimindeki bu önemli savaşların insanı ve yaşadığı toplumu etkilediği gibi bu toplumlarda yaşayan sanatçıları da etkileyerek değişimi sanatlarına yansıttıkları görülmektedir.

\section{2. ÇALIŞMANIN ÖNEMİ (RESEARCH SIGNIFICANCE)}

Dünyaca ünlü bir heykeltıraş bir kaya parçasını yontarken yanına bir çocuk gelir: "Amca, bu kaya parçasının içinde ne arıyorsun?" diye sorar. Heykeltıraş çocuğa gülümseyerek: "İstersen şimdi git, birkaç gün sonra yeniden gel." der. Çocuk bu duruma anlam veremeden oradan uzaklaşır ve birkaç gün sonra geri gelir. Kaya parçasıyken şimdi çok güzel bir at olan heykele hayretle bakar ve: "Amca, bu kayanın içinde at olduğunu nereden bildin?" der. Heykeltıraş: "Her maddenin bir dönüşme yeteneği var, ben sadece bu taşı gördüğün at heykeline dönüştürdüm." der.

Bu hikâyede anlatılan kaya parçasında olduğu gibi dünyada var olan bütün toplumların içerisinde de değişme ve dönüşme potansiyeli vardır. Nasıl bir taş yetenekli bir elin dokunmasıyla güzel bir at heykeline dönüşüyorsa, toplumlar da iyi yöneticilerin ellerinde refah ve huzurlu toplumlara dönüşebilirler. 


\begin{abstract}
Dönüşümlerin olumlu olması için geçmişte yaşanmış olayları bilmek önemlidir. Sadece olayların nasıl olduğunu bilmek yeterli değildir. O dönemde yaşayan insanların hayatlarını savaşın olumsuz etkilediğini tarih bilimciler ortaya koymuştur. Tarihin görsel olmadan aktarılması sadece hikâye etkisi yaratabilir. Bu etkinin kalıcılığı da çok uzun süreli olmaz. Bu etkiyi artırmak o dönemlerde yaşanılan savaşların insanlar üzerinde bıraktığı duygular ile günümüz insanı arasında bir bağ kurmak önemlidir. Bu çalışmada olduğu gibi savaş dönemlerinde yaşamış sanatçıları literatür tarama yöntemiyle ele almak, onların yaşadıkları olayları ve duyguları yaptıkları sanat eserleriyle birlikte ortaya koymak önemlidir. Ayrıca, bu sanat eserlerini günümüz insanının önüne getirerek bu eserlerin yapıldığı dönemin duygusuyla "empati" kurmalarını sağlamak da çok önemlidir. Bu çalışmanın amacı da bu duyguları geliştirmek ve insanların yaşadıkları dönemlerdeki huzurlu ortamlara sahip çıkmalarının önemli olduğunu ortaya koymaktır.
\end{abstract}

\title{
3. YÖNTEM (METHOD)
}

Bu çalışmada literatür tarama yöntemi; nitel araştırma yöntemlerinden olan betimsel analiz ve içerik analizi yöntemleri kullanılmıştır. Betimsel analiz yöntemine göre; literatür tarama yöntemiyle elde edilen veriler daha önceden belirlenen temalara göre özetlenir ve yorumlanır. Bu tür analizde amaç elde edilen bulguları düzenlenmiş ve yorumlanmış bir biçimde okuyucuya sunmaktır (Yıldırım ve Şimşek, 2011:224).

İçerik analizi yöntemine göre ise verilerin önce kavramsallaştırılması, daha sonra da ortaya çıkan kavramlara göre mantıklı bir biçimde düzenlenmesi ve buna göre veriyi açıklayan temaların saptanması gerekmektedir. İçerik analizinde temelde yapılan işlem, birbirine benzeyen verileri belirli kavramlar ve temalar çerçevesinde bir araya getirmek ve bunları okuyucunun anlayabileceği bir biçimde düzenleyerek yorumlamaktır (Yıldırım ve Şimşek, 2011:227).

\section{BULGULAR (FINDINGS)}

\subsection{Fransız Devrimi'ni Konu Edinen Sanatçılar ve Resimleri (The Artisti and Their Art Works Included French Revolution)}

Toplumun beklentisine göre siyasi yönetim şeklinin değiştiği bilinmektedir. Aynı durum sanat için de geçerlidir. Toplumun gelişmişlik düzeyi ve kişilerin hayattan beklentileri bu iki kavramı da etkilemektedir.

"Sanat" ve "siyaset"... Her iki kavramın da insanlar üzerinde hem birleştirici hem de ayrıştırıcı etkileri olduğu gerçektir. Genel bir bakış açısıyla "sanat"; hem bireylerin sahip olduğu tüm duygu ve düşünceleri kendilerine özgü bir bakış açısı ile aktarmalarını hem de bu zemin üzerinde geliştirdikleri üslup farklılıkları sayesinde insanların ayırt edici özelliklerini ortaya çıkarmalarını sağlar. Ancak sanat; düşünsel ve kavramsal açıdan tüm bunları sağlamasının yanı sıra diğer taraftan da kitleler üzerinde öyle büyük etkiler yapar ki, bu durum kimi zaman bir çağın kapanıp diğer çağın açılmasındaki en büyük göstergelerden biri olarak da değerlendirilmektedir (Akalın, Başar, Çevik ve Kanat, 2012:9).

Bu durumun en iyi örneklerinden birisi olarak Avrupa'da 18.yy'ın ikinci yarısından itibaren aydınların ve sanatçıların skolâstik düşüncenin (kilisenin yönetimi) ülke yönetiminde aşırı söz sahibi olmasına karşı verdikleri tepki gösterilebilir. Bu tepki zamanla yönetime karşı bir başkaldırıya dönüşmüştür. Amaçlardan biri yönetimi aşırı derecede söz sahibi olan dini liderlerin elinden kurtarmak, akla ve mantığa uygun bir hale dönüştürmektir. 


\begin{abstract}
Edebiyatçılar ülkenin içinde bulunduğu kötü durumu anlatan eserler ortaya koymuşlardır. Çeşitli sanatsal gösterilerin ve var olan durumu anlatan resimlerin halkla buluşması sağlanmıştır. Bu da halkın kültür seviyesinin yükselmesini olumlu şekilde etkilemiştir. Ayrıca bağımsız gazete ve dergiler yaptıkları yayınlarla halkın bilinçlenmesine katkıda bulunmuştur. Bu şekilde halkta bilinçlenme süreci başlamış, halkın bilinçlenmesiyle birlikte yönetime katılma istemi ve seçme hakkı elde etmek için mücadeleler başlamıştır. Bu duruma sınıfsal mücadelenin artık eyleme dönüşmesi denilebilir. Buradaki sınıfın ayaklanmasına ve var olan düzene tepki göstermesine neden olan en büyük etkenlerden birinin sanat ve bu sanatı yapan sanatçıların olduğunu da söylemek doğru olacaktır.

Fransız Devrimínin sonunda sosyo-kültürel yaşamın daha demokratik bir yaşam şekline kavuştuğu ve insan haklarının daha ön plana çıktığı bir yapılanmaya dönüştüğü görülmektedir. Bu dönüşüm sırasında ortaya çıkan halk isyanını ve özgürlük için savaşan insanların otoriteye ve dönemin siyasetine karşı yaptıkları silahlı mücadeleyi, pek çok sanat kolu ve ressamlar konu edinmiştir. Bu ressamlardan olan Lallemand yaptığı sulu boya resimlerle dönemin savaşlarını ve politik olaylarını gün ışığı gibi ortaya koymaktadır. Bu sanatçının dönemin ruhunu yansıttığı en önemli resimlerinden biri Bastille Baskını'nı konu ettiği ve aynı ismi taşıyan resmidir. Bu resim, Bastille Hapishanesi'nde tutuklu olan aydın ve düşünürlerin serbest bırakılması için halkın yaptığı baskını konu edinmiştir. Resmin arka planında hapishane görülmektedir, ön planda ise Fransız askerleriyle halkın çatışma sahnesi yer almaktadır. Hapishanenin her tarafından duman çıkmakta, gökyüzü de adeta dumanlardan gözükmemektedir. Etrafta yıkıntılar oluşmuştur. Sanatçı bu baskın resmiyle; artık bir dönemin yıkıldığını, monarşinin yok olduğunu ve soyluların yerine halkın alacağı yönetimin geleceğini müjdeler gibidir. Soyluların korumacılığını üstlenen askerler yenilmiştir.
\end{abstract}

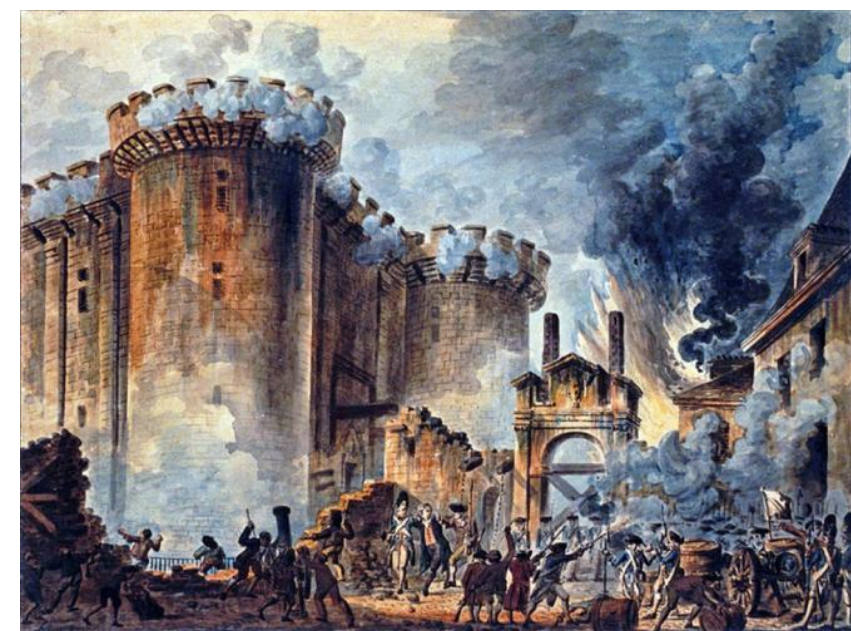

Resim 1. Jean-Baptiste Lallemand, "Bastille Hapishanesi Baskını"

(Picture 1. Jean-Baptiste Lallemand, "Storming of Bastille")

Artık devrimcilerin büyük çaba harcayarak kurduğu "Cumhuriyet Yönetimi" son günlerini yaşamaktaydı. Bunun nedeni 1801'de İtalya'yı fetheden Napolyon'un güçlü bir devlet adamı olmaya başlamasıydı ve 1804'te Napolyon BONAPART Fransız Imparatoru oldu. Napolyon'a başta annesi olmak üzere pek çok insan tepki göstererek yönetim şeklini beğenmediler. Devrimciler de Napolyon'un yönetim şekline karşı geldiler ve ona sırtlarını döndüler. 
Napolyon bu esnada Akdeniz'e erişmek istiyordu ve bunun en basit yolu İspanya'dan geçmekti. Bu durum Fransızlar için İspanya'yı önemli kılıyordu. İspanya'nın başında zayıf bir imparator olan IV. Carlos bulunmaktaydı. Napolyon Carlos'u kandırarak Portekiz'e saldırmayı teklif etti. Carlos bunu kabul etti ve Fransız ordusunun Portekiz'e ulaşması için İspanyol topraklarından geçmesine izin verdi. Napolyon'un amacı ise daha sonra ortaya çıktı. Bu amaç hem Portekiz'i hem de İspanya'yı ele geçirmekti. Napolyon'un askerleri İspanya'ya savaş açtı ve fazla dirençle karşılaşmadı. Fakat bir kesim İspanyol vatansever bu duruma karşı gelerek savaşmayı tercih etti. Bu olay, Fransız askerlerinin Íspanya'da ayaklanan insanları katletmesine kadar gitti.

1814 yılının Şubat ayında Fransızlar İspanya'dan kovuldu. Goya, bu sırada geçici olarak kurulan hükümete giderek kendi savaş kahramanlıklarını ve Fransızların zorba istilasının resmini yapmayı teklif etti, teklif hükümet tarafından kabul edildi. 1808 yılında gerçekleşen 3 Mayıs 1808 katliamı için çalışmaya başladı. Bu resim Fransız ordusuna karşı direnen halkın anısına çizilmiştir.

Goya, Aragonca yazdığı bir mektupta bu tabloları yapma amacını; "Avrupa'nın zorbalarına karşı giriştiğimiz şerefli ayaklanmanın en olağanüstü ve kahramanca hareketlerini fırça darbelerim ile ebedileştirmek" diyerek açıklamıştır (Cirlot, 2007:87).

Goya, "3 Mayıs 1808" adlı tablosunu o kadar çarpıcı bir şekilde yapmıştır ki bu resim bütün İspanya'nın çektiği acının simgesi haline gelmiştir. Bu da bütün kalbiyle katillere ve zorbalığa karşı olan bir sanatçının tepkisidir. Madrid'de gerçekleşen bu katliamda, ülkeyi istila eden Napolyon ordusuna başkaldıran asilerin idam edilişidir. Ama bu eser özellikle İspanya'da çok köklü olan eski bir Hıristiyan inancıyla renklenmiştir. Bu sahnede bir kurtuluş ümidi var gibidir. Kurşuna dizilmek üzere olan asi, çarmıha gerilmiş gibi kollarını iki yana açmış kurtuluşu beklemektedir. Açık avucunda bir yara izi belirmeye başlamıştır. Bu resimde sanatçı ışığı iyiyi kötüye dönüştürmek için kullanmıştır. Tarihte yapılan bütün sanatsal çalışmalarda ışık, temaya yüce bir güzellik kazandırmak için kullanılmıştır. Ama burada durum farklı olarak ışık, katliam aracı olarak kullanılmıştır. Kirli işlerini bir an önce bitirmeye çalışan acımasız askerlerin tüfekleri gecenin karanlığında ışıldamakta ve askerler son emri beklemektedirler (Schama, BBC. Belgesel).

Fenerin yaydığı ışık, burada nesnel anlamda bir ışık olduğu kadar yapıtın plastik oluşumuna da açık leke olarak katkı sağlamıştır. Resimdeki renk dağılımı yine şiddetin ve yıkıcı vahşetin etkisini artırmıştır. Griden siyaha kadar uzanan renk çeşitlerini destekleyen sarı, kahverengi, yeşil ve kırmızı egemenliği şiddetin gerilimini ve olayın gece geçekleştiğini göstermiştir. Goya şiddetin kaynağının otoriteye, güce ve militarizme ait olduğunu belirtmiş ve eleştirel bir tavır sergilemiştir. Resmin trajik yapısı, mekânının öznel seçimi ile oldukça etkilidir. Mekân gecedir; gece gizleyendir, gerçeği, ölümü, şiddeti kapatan ama aynı zamanda gösteren bir hesaplaşma alanıdır. Mekân gösterilen şiddetten ötürü başka konuma geçip, işlevsel açıdan değişime uğramış ve konunun kendisine yönelmiştir. Resim, dramatik olarak şiddeti, kanı, terörü, ölüm ve öldürme temasını gerçekçi bir biçimde vurgulamıştır (Ötgün, 2008:94). 


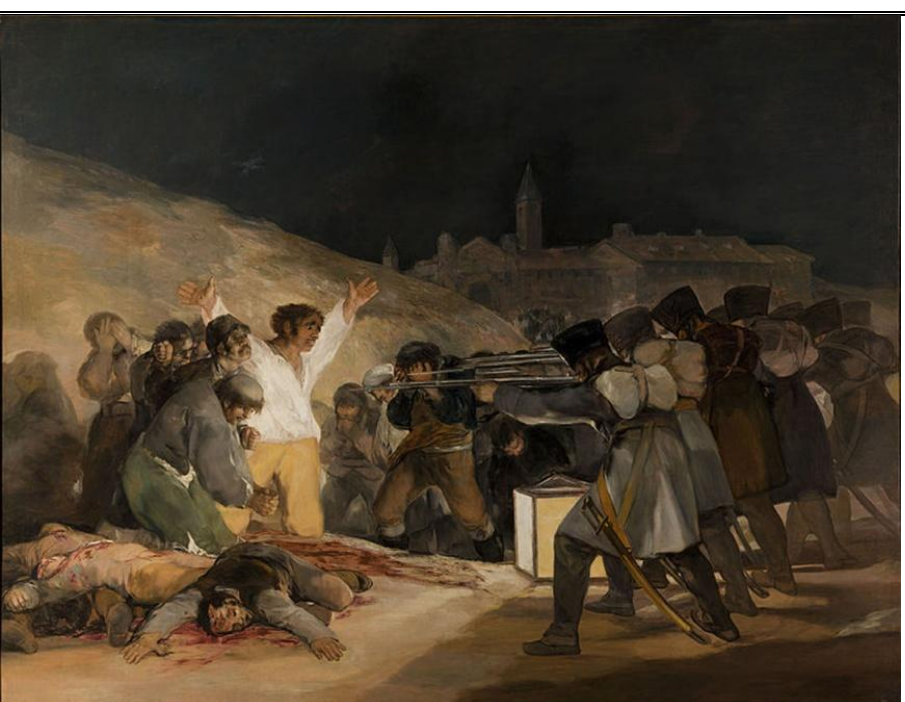

Resim 2. Francisco GOYA, "3 Mayıs 1808 Katliamı", 1814, Prado Müzesi (Picture 2. Francisco Goya "The Third of May 1808" The Prado Museum)

Fransız Devrimi'nden sonra 1830 yılında Avrupa'nın çeşitli yerlerinde devrimler meydana gelmiştir. Özellikle Napolyon'un yenilmesinden sonra 18. Louis, soylulardan ve rahiplerden alınan hakları ve toprakları bunlara iade etmek için yasa çıkarmış, diğer kişilerin elindeki hakları sınırlamış ve basın özgürlüğünü kısıtlamıştır. Bu yaptırımlardan mevcut sanatçılar da etkilenmiştir. Dönemin siyasi olaylarını işleyen sanatçılardan birisi de Delacroix'dir. Sanatçının "Halka Yol Gösteren Özgürlük" adlı eseri oldukça dikkat çekicidir. 1830 Devrimi'ni anlatan bu yapıt şehirde meydana gelen ayaklanmaları anlatmaktadır. Bu eser, politik Fransız resimlerinin efsanevi özgürlük sembolü ile uymamasına rağmen, tabancalı sokak çocuğu ile silindir şapkalı şehir züppesi çağın atmosferini başarıyla yansıtmıştır. Delacroix'in bu resimde belli bir düşünceyi kişileştirme yoluyla anlatma geleneğini gerçekçiliğin yeni üslûbuyla bir araya getirerek alegorik anlatımı yeniden canlandırmaya çalışmış olduğu görülmektedir(Clark, 2011:25). Elinde silah tutan adamlar ve yerde yatan ölüler dikkat çekmektedir. Bu resim, dönemin oldukça kanlı çarpışmalara sahne olduğu gerçeğini gün gibi ortaya koymuştur. 


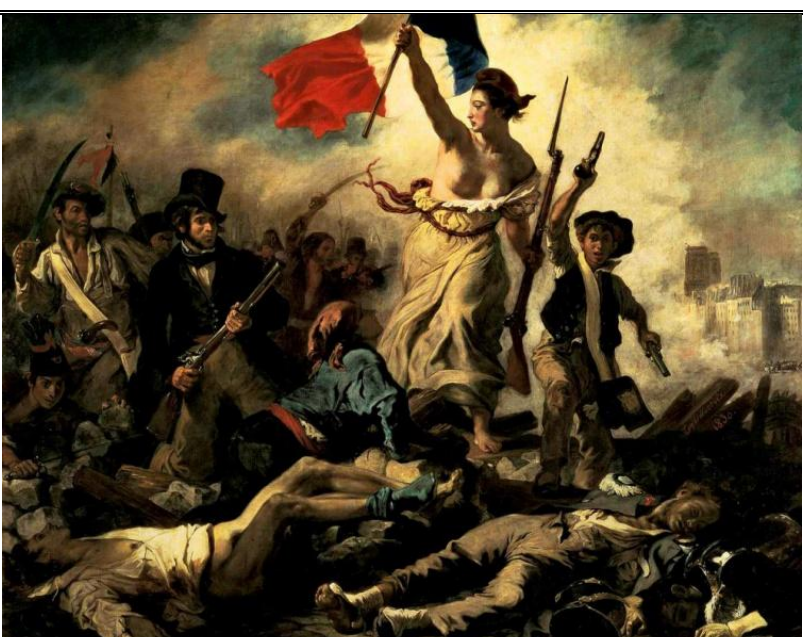

Resim 3. Eugene Delacroix, "Halka Yol Gösteren Özgürlük", 1830, Louvre Müzesi

(Picture 3. Eugene Delacroix "Liberty Leading the People", 1830, Louvre Museum)

\subsection{Birinci Dünya Savaşı ve Alman Devrimi'ni Konu Edinen Sanatçılar (The Artits and Their Painting About World War I and German Revolution)}

Sadece Fransız sanatçılar değil diğer ülkelerde yaşayan sanatçllar da ülkelerinin bulunduğu siyasal durumlara müdahil olmuşlardır. Hatta bazıları aktif olarak bu süreçte boy göstermişlerdir. Bu sanatçılardan birisi de Almanya'da yaşayan Meider'dir.

Meider, 1919 yılında yurttaşı olduğu sanatçılara devrime katılmaları için bir bildiri yayınlamıştır. Bu bildiride: "Bizler özgür ve bilgeyiz, alaylara kılavuzluk eden bayraklar gibi gürbüz kardeşlerimizin önünde dalgalanmalıyız. Ressamlar, şairler... Bu haklı dava uğruna biz savaşmayalım da kim savaşsın?! Dünyanın şuuru tüm gücüyle kalbimizde atıyor hala. Şimdi işçi sınıfı özgürleşmelidir. Aynı zamanda sanatçılar ve şairler de özgürleşmelidir. İnsan saygınlığı, sevgisi, eşitliliği ve adaleti için geleceğin insanlığının kalelerine gidelim. Evet, biz hepimiz eşitiz." demiştir (Artun, 2011:111). Sanatçı bildirisinin dışında sanatıyla da bu siyasi ortama destek vermiştir. Sorunlu olduğunu düşündüğü ortamı resimlerinde betimlemiş ve insanlarda biraz da olsa farkındalık yaratmak adına sergilemiştir.

Ludwig Meider, "Devrim-Barikatlarda Çarpışma" adlı tablosunda, bulundukları ortamın şiddetıi değişkenliğini anlatmaktadır. Sanatçı kendi sözleriyle düşüncelerini "Gece gündüz, kıyamet günü, dünyanın sonu ve kafataslarından oluşan darağaçları ile ilgili saplantılarımı tuvale aktarıyorum; dünyayı sarsacak büyük fırtına o günlerde dişlerini göstermeye başlamıştı ve korkudan titreyerek fırçayı tutan elime parlak, sarı gölgesini düşürmekteydi." diyerek aktarmaktadır. Meider'in sanatının politik yaklaşımı öznel tepkilerini mümkün olduğunca özgün aktarma amacında yatmaktadır (Clark, 2011:27). Sanatçının Delacroix'ten etkilendiği bilinmektedir. Ancak sanatçı yapmış olduğu resimlerde savaş ortamlarını bir kahramanlık destanına çevirmek yerine burada yaşanan acı ve ıstırabı gözler önüne sermektedir. Sanatçı "Devrim-Barikatlarda Çarpışma" adlı eserinde kendi portresine de yer vermiştir. Resmin sol alt tarafında moloz yığınlarının altında kendisini gösteren sanatçının gözlerindeki endişe ve korku hissi hat safhadadır. 


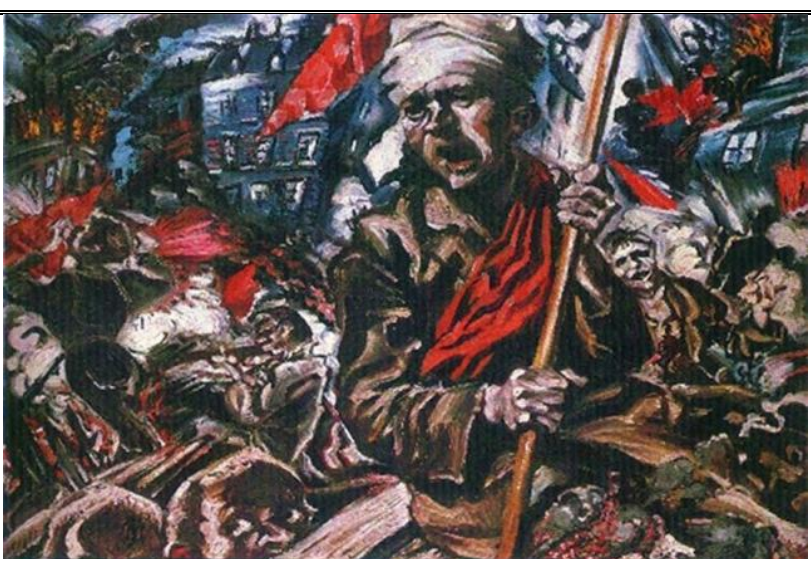

Resim 4. Ludwig Meider, "Devrim-Halka Yol Gösteren Özgürlük", 1913, Genehmigung des Jüdischen Müzesi Frankfurt.

(Picture 4. Ludwig Meider, "Revolution-Clash on Roadblocks" 1913, Genehmigung des Jüdischen Mesums Frankfurt)

\subsubsection{Birinci Dünya Savaşı'ndan Sonra Alman Resmi (The German Painting After World War I)}

Birinci Dünya Savaşı'nın bitmesine yakın Almanya'nın neredeyse yok olma seviyesine gelmiş hali vardı. Bu savaşın içinde bulunan ve bu yıkımı gören Alman sanatçılar duygularını oldukları gibi sanatlarına yansıtmaya başladılar. O zamana kadar görülmemiş boyama şekilleriyle içsel duygu ve tepkilerini yansıtan bu sanatçılara, Ekspresyonist (Dışa vurumcu) dendi. Ekspresyonistlerin sanatlarında; öfke, nefret, kin, korku ve yıkım vardı. Bu duygular yaşadıkları dünyaya, savaşa, ülkeleri yöneten ve insanlığı bu duruma sürükleyen kişilere karşıydı.

Bu dönemin duygularını hem yaşamış hem de resimlerinde yaşatmış sanatçılardan birisi de Max Beckman'dır. Sanatçı Birinci Dünya Savaşı'nın bütün yıkımlarını ve vahşetini bizzat cephede yaşamıştır. Savaş, diğer insanlarda olduğu gibi Beckman'ın ruhunda da şiddetli bir çöküntüye yol açmıştır. Bunun yanı sıra sanatçı resimlerine konu edecek fikirler bulduğu için de anlamsız bir sevinç içindedir. Hem ruhsal durumunun yıkımı hem de dönemin yıkımı sanatçının resminin yükselmesine yol açmış ve resimlerinde hem biçim hem de içerik olarak kökten değişimler meydana getirmiştir. Bu kökten değişimler sonucu yaptığı resimlerin en önemlilerinden birisi "Gece" isimli tablosudur.

1918 Kasım Devrimi'nden sonra şiddet ve karmaşanın egemen olduğu Almanya'da siyasi cinayetler gündemdeydi. Bu bağlamda Beckman'ın bu resmi, kent soylu toplumun ince ve kırılgan cilasını sanki delip geçmektedir. Bu resimde odada bulunan insanlar üç haydudun saldırısına uğramış olarak betimlenmiştir. Haydutlar sanki normal bir şey yapıyormuş gibi odadakilere sadistçe eziyet etmekte, onların ırzına geçmekte ve onları öldürmektedirler. Boğazına ilmik geçirilmiş, kolu ise pipolu bir kişi tarafından burkulan adamın gövdesiyle bacağının duruşu çarmıhtan indirilen İsa'nın duruşunu anımsatmaktadır. Hiçbir soruya yer bırakmayan öyküsüne karşın resim, camsı bir donup kalmışlığın, olayları ve figürleri tuhaf bir biçimde tutsak almasıyla her türlü mantık kuralının dışına çıkmaktadır. Burada dönemin söz gelimi, Spartakist ayaklanmasının şiddetle bastırılması, Karl Liebknecht ve Rosa Luxemburg'un Ocak 1919'da öldürülmesi gibi güncel olaylarına yapılmış göndermeler bulunması akla uygun gibi görünmekle birlikte resimdeki çift anlamlılık ve bilinmezlik egemenliğini sürdürmektedir. Sanatçıdan alıntı yaparak bu resmi açıklamak istersek "Bu resim insana, yazgısına ilişkin bir görüntü vermektedir." (Wolf, $2005: 30)$. 


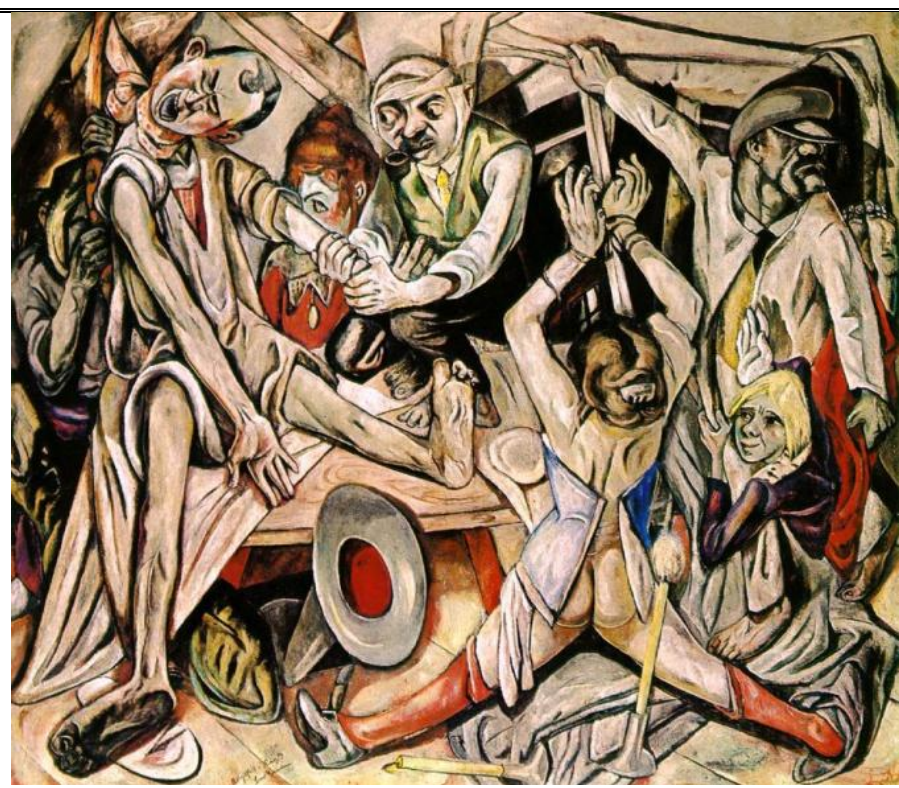

Resim 5. Max Beckman, "Gece", 1918-19, Kunstsammlung NordrheinWestfalen-Düsseldorf

(Picture 5. Max Becman, "The Night", 1918-19 Kunstamnlung NordrheinWestfalen-Düsseldorf)

Bu sanatçılardan bir diğeri ise Alman ressam olan Otto Dix'dir. Sanatçı Birinci Dünya Savaşı'na gönüllü olarak katılan askerlerdendir. Uzun yıllar askerlik yapmış ve zaman zaman hayati önem taşıyan yaralar almıştır. Yaşadığı bu olaylar sanatçının ruhsal durumunda travmatik etkiler yaratmıştır.

Savaşta hayatta kalabilmeyi başarmıştı. İleride bu günlere ilişkin olarak şunları yazacaktı: "Savaş çok korkunç bir şey. Ama görkemli bir yanı da yok değil. Bunu ne pahasına olursa olsun kaçırmamalıydım. İnsanlara ilişkin bir şeyler öğrenmek istiyorsan onları eziyet altındayken görmen gerekir. Yaşamın en berbat yüzünü kendi gözlerimle görmeliydim; işte bu yüzden savaşa gittim, bu yüzden gönüllü oldum." (Wolf, 2005:36). Bu durum askerlik yıllarından sonra yaptığı çalışmaları etkilemiştir. Sanatçı eserlerinde çağdaş Alman toplumunu eleştirmiştir. Konu olarak fahişeler, kasvet, ölüm, savaş ve yaşlılık duygularını ele almıştır. Özellikle savaşın çirkin yüzünü çok sık işlemiştir. Bu durumun farkında olmayan Alman halkının sanki gözüne sokar gibi çirkin, ayakları kopmuş, siperde ölmüş ve iskeletleri kurtlanmış askerlerin resimlerini yapmıştır.

Dix'in önemli resimlerinden birisi de "Prag Caddesi" adlı tablosudur. Bu tabloda birbiri üstüne binmiş perspektifler, aşırı parlak renkler ve parçalanıp bütünlüğü bozulmuş biçimler daha doğrusu çirkin olan her şeyin estetiği vardır.

Bütün bunlar kökenini dışavurumculuktan alan tipik biçimsel özelliklerdi. İşte bu birleştirme sanatını kullanan Dix, genç Weimar Cumhuriyeti'nin kimliğini belirleyen toplumsal adaletsizlikler üzerine Prag Caddesi'yle güçlü bir ışık tutuyor. Yakın bir gelecekteki zorbalık yönetiminde somutlaşacak politik sapkınlıklara dikkat çekiyordu (Wolf, 2005:38). 


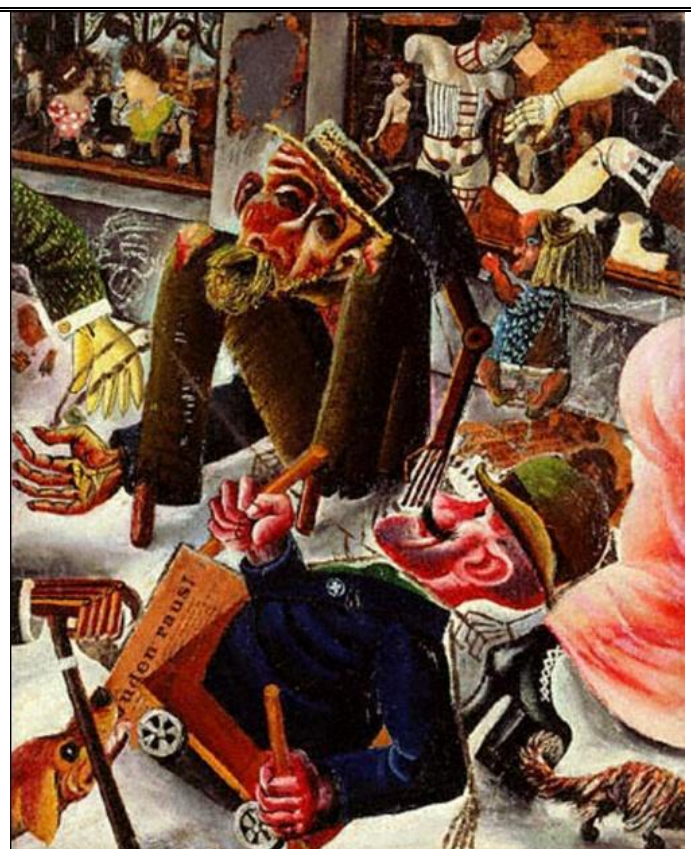

Resim 6. Otto Dix, "Prag Caddesi", 1920, Staatsgalerie-Stuttgard (Picture 6. Otto Dix, Pragerstrasse",1920, Staatsgalerie-Stuttgard)

Dönemin ruhunu anlatan bir diğer önemli resmi de "Metropolis" adlı üçlü çalışmasıdır. Bu resim Birinci Dünya Savaşı'ndan sonra hayatlarını devam ettirmeye çalışan ölümlüleri konu edinir.

Resmin sol tarafında Birinci Dünya Savaşı'nda bacaklarını kaybeden bir asker görülmektedir. Sanatçı bu adamı vatanı uğruna tarif edilemez fedakârlıklar yapmış saygın bir gazi olarak değil, acınacak durumda eksik bir insan olarak betimlemiştir. Sokak köpeğinin saldırgan tavrını, askerin uğruna bacaklarını kaybettiği ülkesi için ne kadar da değersiz olduğunu bir kez daha vurgulamak adına kullanmıştır. Birinci Dünya Savaşı'nın acılarını yine bedeni ile ödeyen başka bir grup da fahişelerdir. Belirgin dişleri, bir elden çok kuş pençesini andıran uçları sivri parmakları ve kemikli vücutları ile yırtıcı bir hayvana benzeyen bu kadınlar, Berlin'in sokak hayatının sembolü haline gelmiştir. Herkesin sokakta hayatta kalmak için mücadele ettiği, insanların gerekirse diğerine zarar vermekten bir an bile kaçınmayacağı, insanlığın nefes almak, yemek ve seks yapmak gibi hayvani ihtiyaçlara indirgendiği post-apokaliptik bir dünya betimlenmiştir. Sağ panelde yine savaşta vücudunun bir kısmını, bu sefer yüzünü kaybederek çıkmış bir askeri görmekteyiz. Artık insana bile benzemeyen bu zavallı adam, bir kenarda oturmuş önünde ilerleyen fahişeler ve fazla süslü zengin kadınlar geçidine selam durmaktadır. Daha da daralan perspektif ile beraber üst üste binen binalar adeta yerde oturan askerin üzerine çökecekmiş gibi durmaktadır. Kapının kemerinin üzerindeki ağzı açık aslan figürü sadece dekoratif bir element değil, sol paneldeki köpek gibi bu cehennem dünyanın gerçek bir tehdit unsurudur. Sağ ve sol paneller sokağın sefaletini anlatırken orta resimde çok farklı bir manzara yer almaktadır. Bir müzikholde şanslı azınlık Amerika'dan yeni ithal edilmiş eğlence kaynă̆ı jazz müzik ile dans edip içkilerini yudumlamaktadırlar. Amerikan etkisinin tüm Avrupa gibi Berlin'i de etkisi altına almasıyla beraber zenci müzisyenler şehre gelmiş, savaş öncesinde operaların hâkim olduğu gece hayatında artık Charleston da vardır. Kadınlar savaş öncesine göre çok daha özgürleşmiş, geçmişe göre teni çok daha fazla açıkta bırakan ve kalçadan oturumuyla hatları erkeksileştiren 
elbiseler bu özgürleşmenin bir sembolüdür. Bob stil saçlar, kadınların eş zamanlı gelişen güçlenme ve erkeksi bir tarz edinme süreçlerinin bir parçasıdır. Orta panel içkileri, hareketli dansları, modern kıyafetleri ve görkemli takıları ile tatıı bir hayatı gösterse de, yine de bizi rahatsız eden bir şeyler var (Zalimoğlu, 2011:http://guzelsanat.wordpress.com).

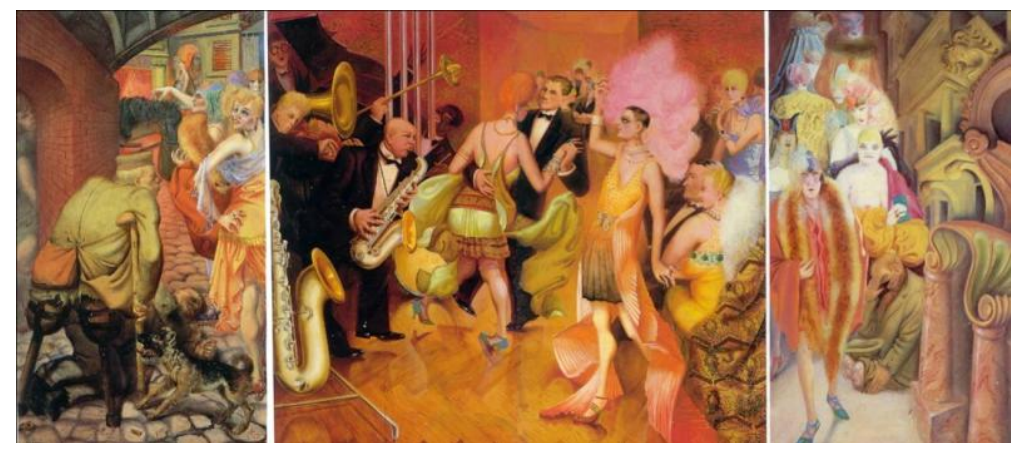

Resim 7. Otto Dix, "Metropolis", 1927-28, Stuttgard Şehir Galerisi (Picture 7. Otto Dix,"Metropolis", 1927-28 Stuttgard City Gallery)

George Grosz da arkadaşı olan otto Dix gibi savaşa gönüllü olarak katılan sanatçılardan birisidir. O da, savaşın insanlara neler yaptığını ve üzerlerinde bıraktığı etkiyi bilmek istemektedir. Bu olumsuz duyguları gözlemlemekle kalmayıp bizzat kendisi de yaşamıştır. 1914 yılında kaydolduğu ordudan askerliğe elverişsizdir raporu verilerek terhis edilmiştir. 1917 yılında tekrar askere alınmış ve bir gün sonra revire kaldırılmış, yine askerliğe elverişsizdir raporu verilmiş ancak bu sefer gittiği yer ülkesi değil bir akıl hastanesi olmuştur.

Ordunun içinde bulunduğu süre onun savaşa ve askerliğe olan nefret duygusunu iyice körüklemiş, bir süre sonra buna savaştan çıkar sağlayanlara karşı duyduğu tiksinti de eklenmiştir. Grosz'un savaş yıllarında ele aldığı konular sirk ve varyete gösterileri, suç ve cinayet olayları, savaş ve büyük kentlerdir. Özellikle bu sonuncusu, sanatçı için çivisi çıkmış bir dünyayla eş anlamlıdır (Wolf, 2005:42).

Grosz'un "Oskar Panizza'nın Anısına" adlı eserinde resmini yapmak için edindiği konuların hepsine rastlamaktayız. Ağırlıklı olarak kulıandığı kırmızı renk ve şehrin içindeki kalabalık adeta resme panayır havasının enerjisini vermiştir. Ancak bu resimdeki enerji eğlencenin değil; ölümün karşısında şuursuzca ne yapacaklarını bilmeyen pusulasını şaşırmış, ellerini kollarını sallayan insanların enerjisidir. Resimde bir karmaşa vardır. Küçük bir kilise ve etrafında gece kulüpleri, barlar ve iş hanları kentin bütün karmaşasını anlatmaktadır. Resimde kılıcını sallayan madalyalı bir subay, mahşer yerini andıran kalabalığın ortasında kalmış ve elinde hacını havaya kaldırmış bir rahip, karnaval havasını yaşayan ve çeşitli müzik aletleri çalan insanlar, din adamının önünde suratı koyuna benzeyen bir büro çalışanı, artık insanların koyun gibi yaşadığını sembolize etmektedir. Özellikle tabutun yanındaki kapıda yazan "HEUTE TANZ" (gece boyu dans) her şeyi açıklamaktadır. Bu resim modern bir ölümün dansıdır. Modernleşme ve güçlenme adına yapılan savaşlar adeta insanların ruhsal ve bedensel dengelerini bozmak için yapılmıştır.

Sanatçı bu protest resmi aklını kaçıran insanlığın artık bir yerde durması için yapmıştır. 


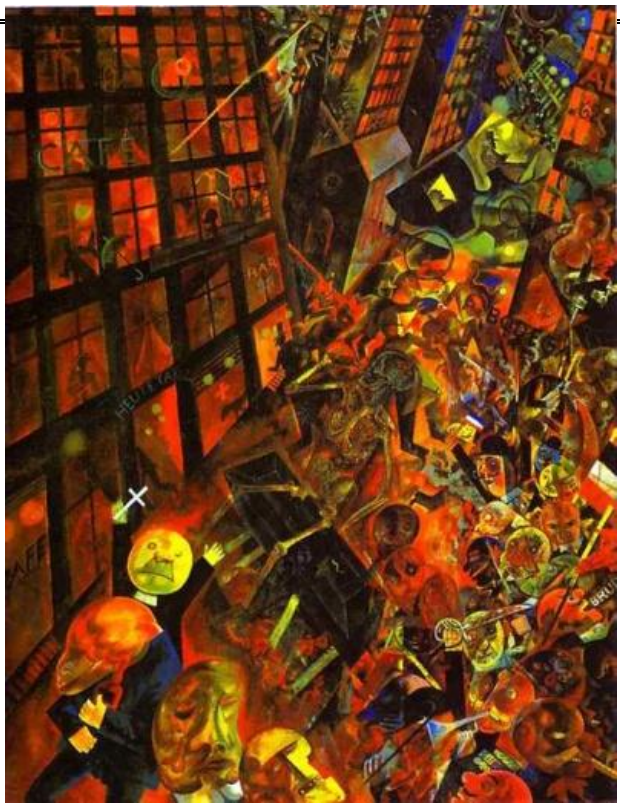

Resim 8. George Grosz, "Oskar Panizza'nın Anısına", 1917, Staatsgalerie Stuttgart-Germany

(Picture 8. George Grosz "Homago to Oskar Panizza", 1917, Staatsgalerie Stuttgard-Germany)

\subsubsection{Birinci Dünya Savaşı'ndan Sonra Türk Resmi (The Turkish Painting After World War I)}

Birinci Dünya Savaşı'nın olduğu dönemler ülkemizi de derinden etkilemiştir. Dünyanın siyasi ve sanatsal durumu yukarıda anlatılan gibiyken, ülkemizde yani yeni kurulma aşamasında olan Türkiye'de nasıldı? Türk sanatçılar ülkelerinin durumunu nasıl algılıyorlardı? Sanatçlar tuvallerine veya kullandıkları herhangi bir sanat malzemesine ülkelerinin içinde bulunduğu durumu ve kendi ruhsal durumlarını nasıl yansıtıyorlardı?

Savaş yıllarında Avrupa'da savaş karşıtı anarşist eylemleri ve devrimci söylemler ortaya koyan Dadaizm gibi sanat akımları gelişirken İstanbul'da durum biraz daha farklıdır. Milli duyguların eserlerine yansıtıldığı romantik bir sanat dönemi hâkimdir. Bunun nedeni ise Osmanlı Devleti'nin Balkan Savaşları'nın yorgunluğunu henüz üzerinden atamamışken, kendisini Birinci Dünya Savaşı'nın içinde bulmasıdır. Bu durumun ülkede yaşayan insanlarda moral bozukluğu ve çöküntü oluşturması normaldir. Bu olumsuz durumları aşmak, halkın milli duygularını tetiklemek ve moral bozukluğunu ortadan kaldırmak için sanatçılara büyük görev düşmektedir. Bunu da halkın milli moral değerlerini yükseltecek ve yüceltecek kahramanlık yapıtları ortaya koyarak ve bu yapıtları sergileyerek olacağını düşünen devlet ve Harbiye Nezareti desteklemiş ve organize etmiştir. Bu organize durumun en belirgin hareketi; 1910 yılında Paris'e sanat eğitimi almaları için gönderilen gençlerin Birinci Dünya Savaşı'nın patlak vermesiyle birlikte ülkeye geri çă̆rılması olmuştur. Bir kısım sanatçı ise kendi isteğiyle geri dönmüştür (Altıntaş, 2007:27).

Ülkeye geri dönen sanatçıların çalışması ve ülkenin moral bozukluğunu üzerinden atabilmesi için Harbiye Nezareti'nin, İstanbul'un Şişli semtinde kurduğu atölye önemlidir. Bu atölye Çallı kuşağı adı verilen ressamların çok sık uğradığı ve resim yaptıkları yer haline gelmiştir. Buradaki modeller bizzat askerlerden oluşan canlı modellerdir. Sami Yetik ve Mehmet Ali Laga gibi bazı sanatçılar direkt savaş ortamlarına gitmiş ve burada eskizler çizmişlerdir. Bu 
eskizlerle Şişli atölyesinin çalışmasına destek vermişlerdir. Bu atölye bir fikir uğruna bir kısım sanatçının bir araya gelerek çalışmasını sağladığı için Türk sanat tarihinde önemıi bir yere sahiptir.

Atölyede sanatla uğraşan ve bir döneme adını veren İbrahim Çalıı'nın önemli eserleri bulunmaktadır. Bu eserlerden birisi de "Topçu Mevzi Alırken" adlı tablosudur. Sanatçı diyagonal bir kompozisyon kullanarak oluşturduğu bu eserde, bir kısmı yaya bir kısmı atlı olan askerlerin tüm imkânsızlıklara rağmen bir top arabasını yürütmek için harcadıkları çabayı betimlemiştir. Bu resimdeki enerji ve çaba izleyen insanlara geçmektedir. Sanatçı bu resimde hem var olan durumu ortaya koymuş hem de umutsuz olan insanlara umutlarını kaybetmemeleri ve en olumsuz şartlarda bile direnmeye devam edilmesi gerektiğinin mesajını vermiştir. Bu atölyenin en önemli özelliklerinden birisi de aslında budur, sanatla insanlara umut ve direniş aşılamak. Sanatçı bu eseriyle dönemin ve atölyenin genel özelliklerine uymaktadır.

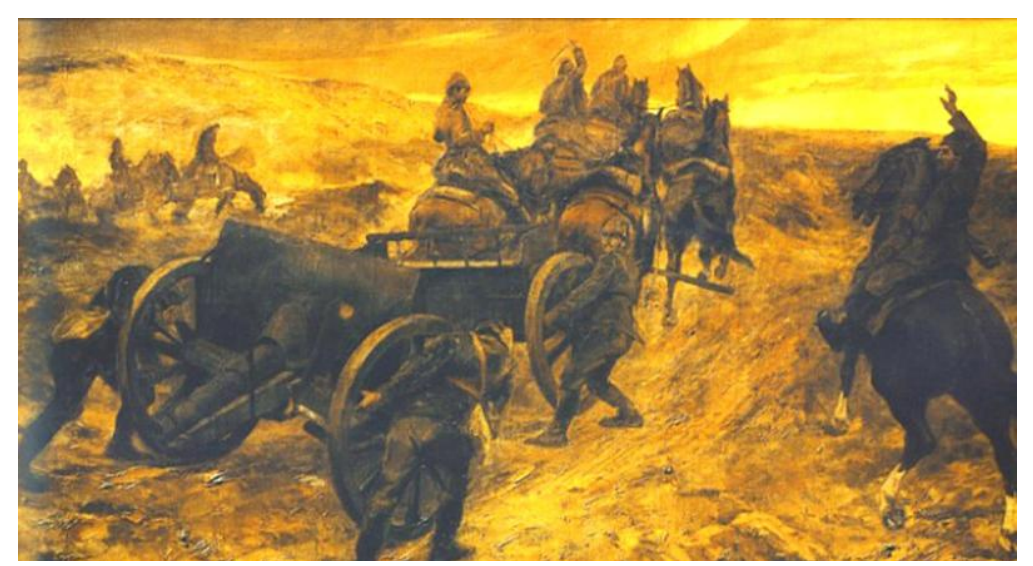

Resim 9. ̇̇brahim ÇALLI, Türk Topçularının Mevzie Girişi, 1917, M.S.Ü. Resim ve Heykel Müzesi.

(Picture 9. İbrahim ÇALLI, "The Access of the Turkish Artillery to Emplacement" 1917, M.S.U. Museum of Fine Arts)

Şişli atölyesinin dışında çalışmalarını sürdüren bazı sanatçılar da vardı. Bu sanatçılardan birisi de yine eğitimini yurt dışında almış ve Birinci Dünya Savaşı öncesinde yurda dönmüş olan Hüseyin Avni Lifij'tir.

Sanatçının 1916 yılında yaptığı "Karagün" adlı tablosu aynı dönemi paylaştığı diğer ressamların konu seçimiyle benzerlik göstermektedir. Lifij de savaşı konu edinmiştir. Ancak sanatçının kullandı figürler diğer sanatçıların savaş resimlerinde kullandıkları figürlerden farklı bir şekilde yapılmıştır. Diğer sanatçılar figürleri kahramanlaştırarak kullanırken, Lifij'in "Karagün" adlı tablosunda savaş alanında çıplak ve yarı çıplak figürler kullanmıştır. Bu tavır sanatçının var olan durum hakkındaki gözlemleri sonucunda ortaya çıkmıştır. Ancak sanatçının eserlerini oluştururken başvurduğu düş gücünü de yabana atmamak gerekir. Bu resmin ön tarafında yani resmin merkezinde, solda yarı çıplak yaşlı bir kadın, onun sağında üzerinde hiçbir kıyafet bulunmayan genç bir kadın ve ikisinin önünde arkası dönük ve sadece kalçalarının altını örten kırmızı bir bez parçasıyla bir kadın resmetmiştir. Arka planda bir göl, kızıl renkli bulutların bulunduğu bir görünümün önünde tekerleği kırılmış bir araba, yere düşmüş bir at, dala yaslanmış yaşlı bir adam ve resmin sağ bölümünde puslar içerisinde kalmış birkaç figür yapmıştır. Şişli atölyesinde 
çalışan diğer ressamlarla karşılaştırıldığında Lifij'in resimlerinin daha insancıl olduğunu düşünebiliriz. Eserinde savaşan askerleri değil, düşmanların baskınlarından sonra sivillerin düştüğü dramatik durumu ele almıştır. Lifij'in Fransız işgaline karşı tepkili olduğu bilinmektedir. Bu resimde Fransızların işgallerine ve yaptıkları zulme karşı bir tepki de vardır.

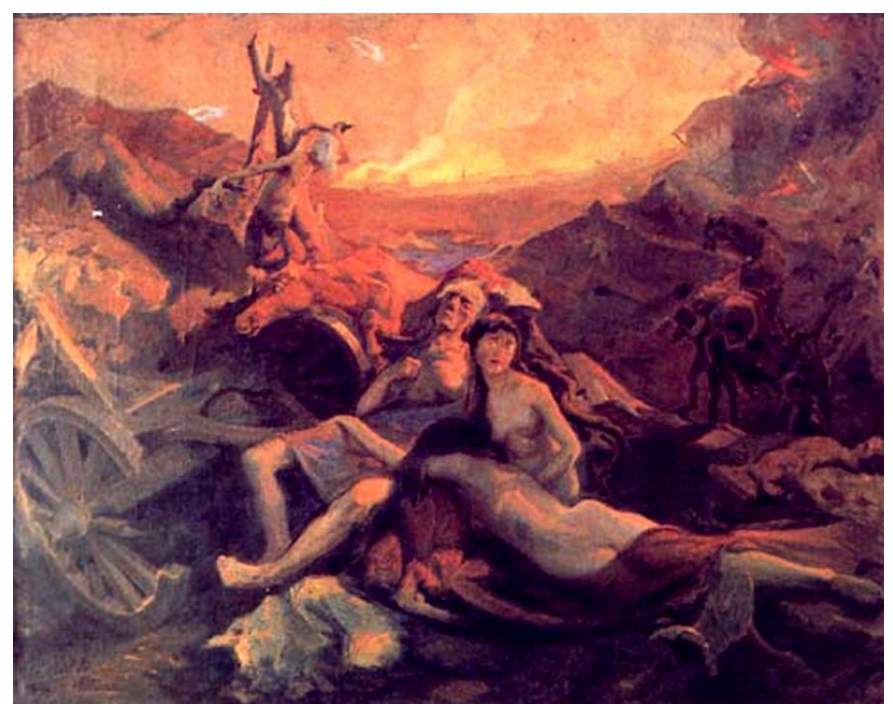

Resim 10. Hüseyin Avni LİḞJ, "Karagün", 1916, Ankara Resim ve Heykel Müzesi

(Picture 10. Hüseyin Avni LífíJ, "Approvet "1916, Ankara Painting and Sculpture Museum)

\subsection{Vietnam Savaşı'nı Konu Edinen Sanatçılar (The Artists and Their Painting About Vietnam War)}

Asya bölgesinde yayılmaya başlayan komünist rejim, Amerika'nın bu bölgeyle ilgili siyasi beklentilerini olumsuz yönde etkileyeceğini düşünmesi bu savaşın başlıca nedenlerinden biridir. Savaşın fiilen başlaması 1965 yılına denk gelmektedir ve sekiz sene kadar sürmüştür. Amerikan halkı savaşın nedenine bir türlü anlam verememiş ve ülkelerinin böyle bir savaşın içinde yer almasını istememişlerdir. Bu savaş esnasında Amerikan askerlerinin çok kayıp vermesi üzerine var olan federal hükümete karşı başkaldırılar da olmuştur. Özellikle büyük kentlerde ve üniversitelerde bu savaşa karşı protesto gösterileri yapılmıştır.

Halk bu tepkileri verirken sanatçılar da boş durmamıştır. Gereksiz ve bir türlü anlamlandıramadıkları savaşa karşı protest resimler ve projeler yapmışlardır. Dönem sanatçıları sanatın politik mücadele karşısında tarafsız kalması düşüncesini reddetmişlerdir. Sanat ve politikanın bildik söylemlerinden kaçınan eylemler yaratmışlardır. Bu eylemler genellikle saygısız ve muhaliftir; genellikle bir sanat okulu veya üniversite kampüsünü forum alanı olarak kullanarak akademik kurumlara yönelmiştir. Örneğin, 1970 yılında Terry Fox, Berkeley Üniversitesi'nin Sanat Müzesi önündeki çiçekleri Vietnam Savaşı'nda kullanılan ve ateş püskürten bir makineyle yakmıştır. Bu performansına da "Yaprak Dökülmesi" ismini vermiştir (Clark, 2011:150).

Terry Fox'un yaptığı performans dışında birçok sanatçı çeşitli çılgınlıklarda gösteriler yapmışlardır. Bunlardan bazıları kendilerini kolundan tüfekle vurdurmuş, bazıları kırılmış cam parçalarının üzerine 
yatıp bedenini şiddete maruz bırakmış ve bu şekilde savaşta yaşanan acılara dikkat çekmek istemişlerdir.

Resimlerinde savaş karşıtı temalar işleyen önemli sanatçılardan birisi de Leon Golub'tur. Glob'un resimlerinde siyasi hükümetlerin kendi çıkarları için yaptıkları şiddeti ve terörü, insanların alanlarda öldürülmesini, işkence odalarını, barlardaki ve genel evlerdeki bohem hayatı, ırkçılığı, cinsiyet sorunlarını, insanlara yapılan baskı ve dışlamaları görmek mümkündür.

Sanatçı "Soruşturma" adlı resim dizisindeki figürleri hakkında "Amerika'nın iktidarını ya da genelde iktidar biçimlerini anlamak için periferilere bakmak gerek. Hükümetler ve uzantıları merkezi kontrol kullanmak istemedikleri zaman ortaya paralı askerler çıkar. Hükümetlerin bunlarla 'resmi ilişkisi' olmadığı için paralı askerlerin eylemleri hem belirsiz hem de açıkça ortadadır." diyerek açıklamıştır. (Ncwman, 1982:11).

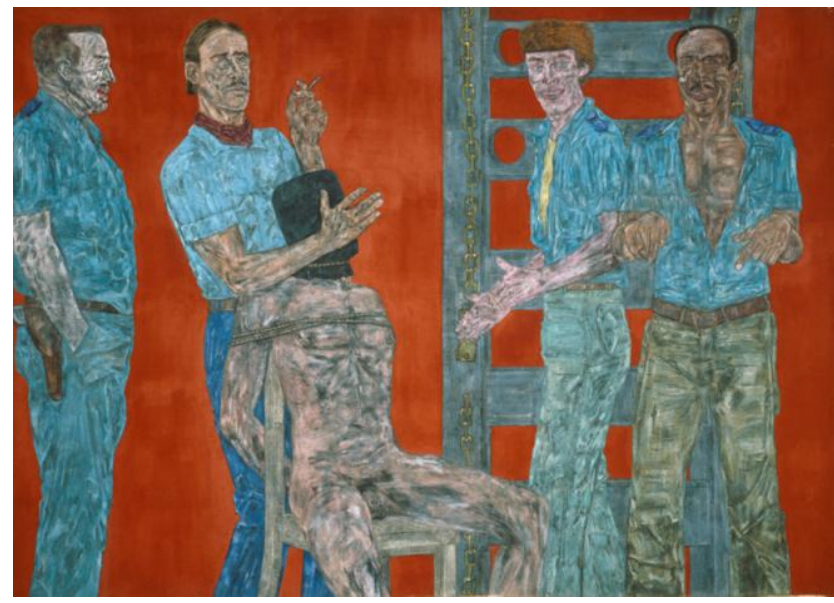

Resim 11. Leon Golub, "Sorgu 2", 1981, Çă̆daş Sanatlar Derneğine hediye 1983 yılında hediye edilmiştir

(Painting 11. Leon Golub, "Interrogation II" 1981, Gift of Society for Contemporary Art 1983)

Leon Golub'un dışında Vietnam Savaşı'na karşı olan ve bu konuda eser veren birçok sanatçı vardır. Bunların başını "Vietnam Savaşı sanatçı olarak konumumu yeniden düşünmemi să̆ladı." diyen Nancy Spero çekmektedir. Bunun dışında Carl Andre ve Ad Reinhardt gibi sanatçılar topluluklarda bu konu üzerine çok sayıda eser üretmiş ve savaşa karşı protest duruşlarını bozmamışlardır.

\section{SONUÇ (CONCLUSION)}

Bu Çalışmada Fransız Devrimi, Birinci Dünya Savaşı ve Vietnam Savaşı'nı konu edinen sanatçılar ve resimleri incelenmiştir.

Toplumun beklentisine göre siyasi yönetim şeklinin değiştiği bilinmektedir. Aynı durum, sanat için de geçerlidir. Toplumun gelişmişlik düzeyinin ve hayattan beklentilerinin sanatı etkilediği ortadadır. Bu bağlamda savaşları yaşamış ve bu durumdan etkilenmiş sanatçıların eserleri yoluyla duygularını ortaya koydukları saptanmıştır. Her dönemin sanatçısı kendi yaşadığı dönemi yetenekleri ve sanatsal üslubu doğrultusunda ortaya koymuştur. Aynı zamanda ortaya konan bu eserlerin sonraki nesiller etkileyeceği ve onlara örnek teşkil edeceği de düşünülmektedir.

Sonuç olarak bu çalışmada incelenen eserler, üretim zamanları, üretildikleri koşullar ve teknik olarak farklılık gösterseler bile duygu yönünden oldukça benzerlik göstermektedirler. 


\section{KAYNAKLAR (REFERENCES)}

1. Akalın, T., Başar, G., Çevik, S.K. ve Kanat, S., (2012). 1983'ten Günümüze Siyasi Partilerin Kültür ve Sanat

Politikaları. Ankara: Öncü Yayınları.

2. Altıntaş, O., (2007). Sanat Eğitimi ve Çağdaş Türk Resminde Nü. Ankara: Sur Yayıncılık.

3. Artun, A., (2011). Sanat Manifestoları Avangard Sanat ve Direniş. İstanbul: İletişim Yayınları.

4. Clark, T., (2011). Sanat ve Propaganda. Çev: Esin Hoşsucu. İstanbul: Ayrıntı Yayınları.

5. Crrlot, L., (2007). Francisco de Goya. İspanya: Prado Müzesi II, «Dünyanın Müzeleri», Bölüm 7 .

6. Kreft, L., (2011). 20. Yüzyılda Sanat ve Siyaset. Editör: Ali Artun. "Sanat Siyaset". İstanbul: İletişim Yayınları.

7. Ncwman, M., (1982). Leon Golub, Michael Ncman'la söyleşi.London: Catolog, Institute of Contemporary Arts.

8. Ötgün, C., (2008). Sanatın Şiddeti ve Sınırları. Ankara: Gazi Üniversitesi Sanat ve Tasarım Dergisi. Sayı: 1, ss:90-103.

9. Schama, S.Pablo Picasso. BBC Sanatın Gücü Adlı Belgesel.

10. Yıldırım, A. ve Şimşek, H., (2011). Sosyal Bilimlerde Nitel Araştırma Yöntemleri. Ankara: Seçkin Yayınları.

11. Zaimoğlu, M., (2011). Dönemim Ruhu Otto- Dix Metropolis, 1928. http://guzelsanat.wordpress.com/category/uncategorized. Erişim: 13.04 .2013 .

12. Wolf, N., (2005). Dışavurumculuk/Ekspresyonizm. İstanbul: Taschen ve Remzi Kitapevi Ortak yayını. 